\title{
Reef fish assemblages: a re-evaluation using enclosed rotenone stations
}

\author{
John L. Ackerman*, David R. Bellwood \\ Department of Marine Biology, James Cook University, Queensland, 4811, Australia
}

\begin{abstract}
The reef fish assemblage at Orpheus Island, Great Barrier Reef, was examined using visual censuses and the ichthyocide rotenone. Small $3.5 \mathrm{~m}^{2}$ quantitative rotenone samples, using a fine-mesh net to enclose the site, were compared with visual-point censuses (prior to the placement of the net), random-point censuses and strip censuses. Furthermore, the fishes collected inside and outside the net were examined to determine the relative efficiency of enclosed versus open rotenone samples. Rotenone samples comprised 128 species in 28 families. Of these, only $49 \%$ of the species overlapped between the enclosed (inside net) and open (outside net) samples. Only $17.7 \%$ of the species in the enclosed rotenone sample were seen prior to collection. Rotenone samples reveal that visual censuses underestimated the abundance of small taxa. Overall, rotenone samples increased the estimated number of species by $40.4 \%$ and the total fish abundance by $50.1 \%$ ( $75.3 \%$ for fishes $<50 \mathrm{~mm}$ ). Biomass increased by less than $1.0 \%$. However, through relatively high energetic demands, high turnover rates and their role as potential prey, small fish taxa may play a greater role in reef processes than previously assumed. The limits of visual censusing techniques are highlighted, emphasising the value of small, enclosed, intensive rotenone samples for providing reliable quantitative samples of small taxa.
\end{abstract}

KEY WORDS: Rotenone - Fish assemblages - Visual census · Abundance - Diversity $\cdot$ Coral reef · Biomass · Great Barrier Reef

\section{INTRODUCTION}

Reef fish assemblages are amongst the most diverse vertebrate assemblages in the world (Choat \& Bellwood 1991, Caley 1995). Hundreds of species varying in size, shape and colour can often be found within a relatively small area (Bell \& Galzin 1984, Parrish et al. 1986). This diversity alone can make the identification and quantification of coral reef fish assemblages difficult. Further complications arise with the possibility that numerous small cryptic fishes inhabit the reef matrix (Munday \& Jones 1998). Studies of reef fish assemblages often note that small fish are disregarded due to the inherent difficulty in accurately censusing small taxa (Jones \& Chase 1975, Shepherd et al. 1992). This has the potential to change any theoretical con-

*E-mail: john.ackerman@jcu.edu.au clusions based on the observed patterns (Blackburn \& Gaston 1996). To gain a full understanding of how an assemblage is structured, a census technique is required that is accurate enough to provide a complete picture of the fish community.

Wide arrays of censusing techniques have been utilised to provide qualitative and quantitative descriptions of reef fish assemblages. These can be divided into 2 basic categories, destructive and non-destructive. Destructive techniques (e.g. nets, traps, spears, explosives and ichthyocides) remove fishes from a particular area. These methods are rarely used for ecological studies because of the impact on the study assemblages. Non-destructive techniques avoid this problem, but they are primarily restricted to visual censuses, either directly or through video cameras. Most visual censuses are derivatives of Brock's (1954) visual reef fish population-estimation technique. 
Visual techniques can be broadly divided into 2 categories, fixed transects or timed swims. In the former, fishes are counted as the observer swims along transects of pre-defined widths and lengths, permitting estimation of densities (e.g. Choat \& Bellwood 1985, Meekan et al. 1995). The second category uses time in place of area, providing estimates of the relative composition of fish assemblages (e.g. Williams 1982, Meekan \& Choat 1997). The inherent biases and errors associated with visual estimates have been examined numerous times (e.g. Davis \& Anderson 1989, St John et al. 1990, Watson et al. 1995). Overall, visual censuses tend to underestimate fish densities (Sale \& Douglas 1981), especially those of small (Bellwood \& Alcala 1988) and/or cryptic species (Brock 1982). Other potential sources of error include fish mobility (Watson et al. 1995), observer experience (Thompson \& Mapstone 1997), and transect width and length (Fowler 1987).

Whilst biases in visual estimates are recognised, they remain an acceptable limitation of visual censusing techniques. They are widely used in studies concerning reef management (Russ 1989), assemblage patterns (Caley \& St John 1996), ecological processes (Hixon \& Beets 1993, Sale et al. 1994), biogeographic patterns (Williams 1982) and evolution (Bellwood 1996). The general consensus appears to be that consistent biases (against smaller/cryptic species) are acceptable for comparative studies. However, the ecological implications of under-representing small/cryptic species has not been addressed.

Destructive techniques, by definition, have an adverse effect upon the fish under investigation. Often they are used in conjunction with visual censuses to augment species lists or estimates of relative abundance (Bell \& Galzin 1984, Bellwood 1996). For assemblages, the 2 main methods have been explosives and ichthyocides. Explosives are relatively non-selective, although fishes lacking swim bladders (muraenids and some gobiids) and those in holes, tend to be underrepresented (Williams \& Hatcher 1983, Bellwood 1996). Of all destructive techniques, rotenone is potentially the least selective (it asphyxiates all fish species), although large mobile species frequently move away, leaving only smaller species within the rotenone plume (Randall 1963, Smith 1973). Rotenone is generally used for qualitative fish collections, e.g. for museum collections or faunal surveys. A few studies have used rotenone in a quantitative manner (e.g. Randall 1963, Brock et al. 1979, Brock 1982, Kulbicki 1990), however, the sample areas are often so large (hundreds of square metres) that the ability to provide an accurate quantitative sample may be questioned.

The contribution of small, cryptic reef taxa to reef assemblages and reef processes is largely unknown.
Before we can critically evaluate the significance of these taxa, we require a method that permits accurate estimates of their relative abundance. Of the methods available, the ichthyocide rotenone appears to be the most promising, despite methodological limitations. The primary aim of this study therefore, is to provide an accurate description of a reef fish assemblage using both destructive (rotenone) and non-destructive (visual) techniques, evaluating the relative utility of open versus closed rotenone stations. In particular, we will focus on the contribution of small taxa to patterns of abundance, diversity, and biomass of fishes on coral reefs.

\section{MATERIALS AND METHODS}

Visual censuses. Visual censuses were undertaken in July 1997 along the northern edge of Pioneer Bay, Orpheus Island $\left(18^{\circ} 35^{\prime} \mathrm{S}, 146^{\circ} 28^{\prime} \mathrm{E}\right)$, Great Barrier Reef. All observations were conducted with SCUBA at 2 to $6 \mathrm{~m}$ depth. Each strip transect was comprised of three $30 \mathrm{~m}$ censuses: a $5 \mathrm{~m}$ wide (swum) census of fishes $>100 \mathrm{~mm}$ total length (TL), a $1 \mathrm{~m}$ wide (swum) census of fish $<100 \mathrm{~mm} \mathrm{TL}$, and finally a $0.5 \mathrm{~m}$ census crawling along the substratum recording any species not previously recorded. This method was designed to pick up the maximum diversity possible for a visual census technique (cf. Bellwood 1996). Prior to each transect, the measuring tape was left for 5 min to permit fish to acclimate. Each census recorded the species, number of individuals, and their estimated total length. Size classes were recorded in increments of $10 \mathrm{~mm}$ up to $100 \mathrm{~mm}, 25 \mathrm{~mm}$ between 100 and $300 \mathrm{~mm}$, $50 \mathrm{~mm}$ between 300 and $400 \mathrm{~mm}$, and of $100 \mathrm{~mm}$ above $400 \mathrm{~mm}$. Fishes in both the benthos and the water column were censused in the 2 swum censuses. In the third (crawl) census holes were examined for fishes and the substratum carefully touched to disturb small or well camouflaged fish (cf. Luckhurst \& Luckhurst 1978). A total of 27 strip transects were completed. The 3 censuses, covering 150, 30 and $15 \mathrm{~m}^{2}$, respectively, were all standardised to $10 \mathrm{~m}^{2}$ then pooled to give an overall estimate of the visually apparent component of the fish assemblage.

Prior to strip censuses, the accuracy of fish-length estimates was evaluated. Fish were anaesthetised with clove oil (Munday \& Wilson 1997) then placed on the substratum in clear plastic bags. Total lengths were estimated from a distance of approximately $2 \mathrm{~m}$, then measured with vernier calipers (to $0.1 \mathrm{~mm}$ ) and the mean percentage error calculated. To assist in estimating lengths during censuses, incremental marks were placed on the recording slates for reference. 
Point censuses $(n=135)$ were undertaken to examine the extent to which the rotenone sites differed from random samples from the area. Point censuses were performed along the same transects as the above strip censuses. Each point census examined an area of $3.5 \mathrm{~m}^{2}$ and extended to the surface. The first point was randomly chosen within the first $10 \mathrm{~m}$, subsequent points were at $5 \mathrm{~m}$ intervals along the transect (total 5 per transect). Approximately $4 \mathrm{~min}$ were spent at each point recording the number of individuals in each species, from a distance of 2 to $3 \mathrm{~m}$. The time and area were chosen to closely replicate the methods used to visually census fishes prior to rotenone samples (see below).

Rotenone samples. Rotenone samples were taken from 2 sites $\mathrm{yr}^{-1}$ from 1993 to 1997 (more intensive sampling was limited by marine park permit-restrictions). The 2 sites were sampled several days apart. Sites were located along the coast from Cattle Bay to Small Pioneer Bay, Orpheus Island, the majority from the fringing reef on the northern side of Pioneer Bay. A small patch of reef was located along the reef slope in 4 to $6 \mathrm{~m}$ and an area of approximately $3.5 \mathrm{~m}^{2}$ was visually censused, recording the number of species and individuals. The area was then covered with a finemesh net (a double-bed mosquito net). The perimeter of the net was weighted with a chain to hold it on the substratum and prevent fishes from escaping. A small float at the apex held the net above the reef. The area covered by the net was approximately $3.5 \mathrm{~m}^{2}$.

Approximately $1 \mathrm{~kg}$ of rotenone powder (in 4 to $5 \mathrm{l}$ seawater with $100 \mathrm{ml}$ of detergent) was pumped into the netted area. It took 10 to $15 \mathrm{~min}$ for the rotenone to completely asphyxiate fishes within the net. Once the rotenone dispersed, 8 to 11 divers collected fishes from within the net using forceps to remove those lodged in corals or holes. The search continued for 20 to $45 \mathrm{~min}$ until all recoverable specimens were removed (i.e. until no new fishes were recovered within a $5 \mathrm{~min}$ period). Two to 4 other divers located and retrieved fishes outside the net. Fishes floating on the surface or in the water column were recovered by 1 to 3 snorkellers. Fishes caught inside (the enclosed rotenone sample) and outside (the open sample) the net were kept in separate containers.

Fishes were placed in an ice-sea water slurry and transferred to the laboratory, where they were identified, counted, fixed in $10 \%$ seawater formalin then stored in $70 \%$ ethanol. Specimens were identified with the aid of the following texts: Masuda et al. (1984), Winterbottom (1984, 1985), Murdy \& Hoese (1985), Winterbottom \& Emery (1986), Myers (1989), and Randall et al. (1990). Each fish was weighed to the nearest $0.001 \mathrm{~g}$, then standard length (SL) and total length (TL) were measured to the nearest $0.02 \mathrm{~mm}$ using vernier calipers.
Data analysis. Principle-components analyses (PCA) (SPSS Version 8.0) were used to examine those components of the fish assemblage that were sampled using the various techniques. Data were $\log (x+1)$-transformed and the analyses performed on the covariance matrices. The first 2 standardised eigenvectors in the component matrix were superimposed within the reduced-space scatterplot of the component scores to produce an h-plot. Total fish biomass was estimated using length-weight regressions taking the mid-points of each size class for each species. The regressions were derived from the literature (e.g. Kulbicki et al. 1993) and from weight-length data from the rotenone collections. Biomass for species without known regressions were calculated using either congeneric or confamilial regressions where maximum size and body shape were similar.

\section{RESULTS}

\section{Visual censuses}

A total of 13991 fishes were visually censused using strip censuses, comprising 146 species in 25 families. The majority of individuals were pomacentrids, gobiids and caesionids (Fig. 1a). These families, along with the Apogonidae, Labridae, Chaetodontidae, Blenniidae, Serranidae and Scaridae comprise over $98 \%$ of the fishes recorded using visual censuses. The top 10 species in the combined visual-strip censuses made up, on average, $78 \%$ of all individuals. The pomacentrids Neopomacentrus bankieri and Pomacentrus moluccensis alone made up nearly $50 \%$ of all individuals censused. Four other pomacentrids, 2 caesionids and 2 gobiids completed the top 10 species (Table 1).

Random-point censuses recorded 80 species in 14 families. The familial composition (Fig. 1b) differed little from that of the strip censuses (Fig. 1), although the gobies are clearly underrepresented. Most families, including the Pomacentridae, appear to be estimated in lower abundances than in strip censuses. Point censuses prior to rotenone samples recorded 19 species in 8 families. Again Neopomacentrus bankieri and Pomacentrus moluccensis dominated consistently with $113( \pm 45 \mathrm{SE})$ and $17( \pm 5 \mathrm{SE})$ ind. per $10 \mathrm{~m}^{2}$, respectively. Caesio cuning and Pterocaesio sp. dominated only once, with $20( \pm 14 \mathrm{SE})$ and 11 ( $\pm 11 \mathrm{SE})$ ind. per $10 \mathrm{~m}^{2}$, respectively. These 4 species made up approximately $94 \%$ of all individuals censused.

Rotenone samples. A total of 3105 fishes (approximately $4.2 \mathrm{~kg}$ ) were collected over the $5 \mathrm{yr}$ period, consisting of 128 species in 28 families. The enclosed rotenone samples emphasise the numerical dominance 

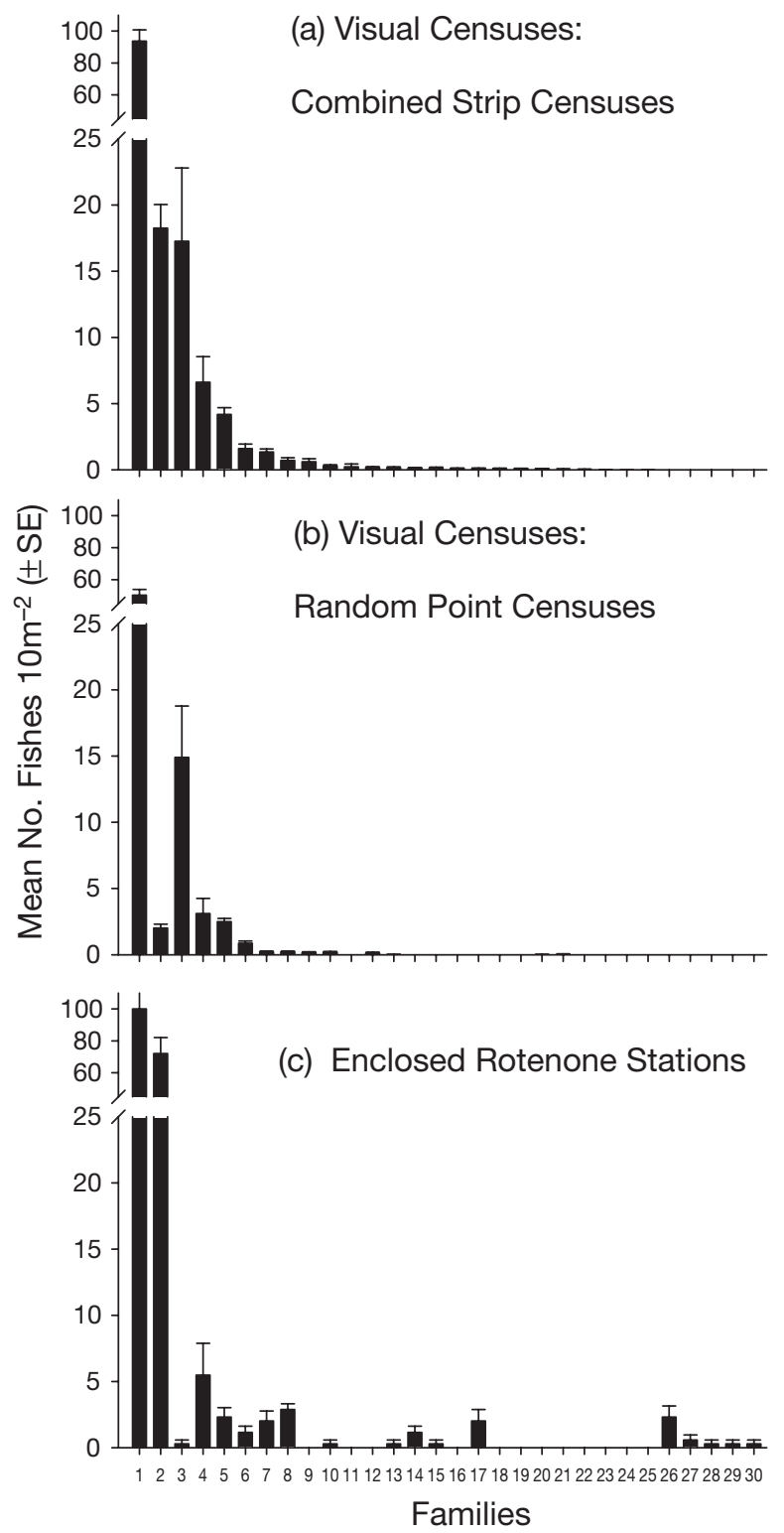

Fig. 1. Mean number of ind. per $10 \mathrm{~m}^{2}( \pm \mathrm{SE})$ within all families. (a) Visual censuses by combined strip censuses $(\mathrm{n}=27)$; (b) visual censuses by random-point censuses of 3.5 diam ( $\mathrm{n}=$ 135); (c) enclosed rotenone samples $(\mathrm{n}=10) .1$ : Pomacentridae; 2: Gobiidae; 3: Caesionidae; 4: Apogonidae; 5: Labridae; 6: Chaetodontidae; 7: Blenniidae; 8: Serranidae; 9: Scaridae; 10: Nemipteridae; 11: Sphyraenidae; 12: Siganidae; 13: Holocentridae; 14: Pseudochromidae; 15: Plesiopidae; 16: Synodontidae; 17: Tripterygiidae; 18: Pinguipedidae; 19: Haemulidae; 20: Pomacanthidae; 21: Lutjanidae; 22: Acanthuridae; 23: Monacanthidae; 24: Ephippidae; 25: Fistulariidae; 26: Bythitidae; 27: Syngnathidae; 28: Muraenidae; 29: Antennariidae; 30: Aploactinidae

of the Pomacentridae and Gobiidae (Fig. 1c). Other taxa were collected in much smaller numbers. The importance of the Gobiidae is further emphasised in the species abundances (Table 2). Whilst Neopoma-
Table 1. Combined strip transects $(n=27)$. Mean number of individuals and mean estimated total lengths of top 10 species

\begin{tabular}{|c|c|c|c|c|}
\hline \multirow[t]{2}{*}{ Species } & \multicolumn{2}{|c|}{ No. per $10 \mathrm{~m}^{2}$} & \multicolumn{2}{|c|}{ Length (mm) } \\
\hline & Mean & SE & Mean & SE \\
\hline Neopomacentrus bankieri & 53.3 & 5.2 & 41.3 & 0.1 \\
\hline Pomacentrus moluccensis & 16.7 & 1.2 & 36.9 & 1.4 \\
\hline Caesio cuning & 10.2 & 2.7 & 173.7 & 0.3 \\
\hline Pterocaesio sp. & 7.1 & 3.5 & 160.6 & 1.5 \\
\hline Eviota sp. G & 6.1 & 0.9 & 28.9 & 0.5 \\
\hline Chrysiptera rollandi & 5.8 & 0.4 & 37.6 & 0.3 \\
\hline Pomacentrus brachialis & 5.2 & 0.6 & 46.6 & 0.5 \\
\hline Neopomacentrus azysron & 3.4 & 0.9 & 51.9 & 0.3 \\
\hline Amblygobius rainfordi & 2.9 & 0.4 & 55.6 & 0.6 \\
\hline Pomacentrus adelus & 2.6 & 0.2 & 51.7 & 0.8 \\
\hline Others & 32.4 & & & \\
\hline Total & 145.7 & & & \\
\hline
\end{tabular}

centrus bankieri and Pomacentrus moluccensis are the most abundant, 6 of the next 8 most abundant species were gobies, including 1 with numbers comparable to those of $P$. moluccensis.

Marked differences were evident between the open and enclosed rotenone samples. Only 62 species $(48.4 \%)$ and 16 families $(57.1 \%)$ were common to both. In both methods, the top 2 species were Neopomacentrus bankieri and Pomacentrus moluccensis. Thereafter, differences between the 2 samples were more marked, with a clear under-representation of cryptic gobiid species in open samples (Table 3 ). In enclosed samples, 6 of the top 10 species were gobies; 3 from the genus Eviota (a genus of small fish generally $<25 \mathrm{~mm}$ TL), 2 were Gobiodon spp. (a genus closely associated with complex branching corals), and 1 was Trimma striata (a cryptic species often found in caves or crevices). The external sample also included a substantial

Table 2. Enclosed rotenone samples $(n=10)$. Mean number of individuals and mean total length of top 10 species. Lengths were measured from preserved specimens

\begin{tabular}{|lrrrr|}
\hline \multirow{2}{*}{ Species } & \multicolumn{3}{c}{$\begin{array}{c}\text { No. per } 10 \mathrm{~m}^{2} \\
\text { Mean }\end{array}$} & \multicolumn{2}{c|}{$\begin{array}{c}\text { Length } \\
\text { Mean }\end{array}$} & SE \\
\hline Neopomacentrus bankieri & 63.1 & 13.2 & 39.3 & 0.4 \\
Pomacentrus moluccensis & 21.6 & 5.2 & 36.0 & 1.1 \\
Eviota queenslandica & 21.3 & 5.9 & 18.9 & 0.2 \\
Pomacentrus adelus & 4.6 & 1.4 & 52.6 & 2.7 \\
Neopomacentrus azysron & 4.3 & 1.8 & 49.4 & 2.0 \\
Eviota sp. C & 3.7 & 1.5 & 20.0 & 0.5 \\
Eviota sp. F & 3.7 & 1.1 & 21.8 & 0.8 \\
Gobiodon histrio & 3.7 & 1.4 & 31.6 & 3.2 \\
Trimma striata & 3.7 & 1.5 & 28.7 & 0.6 \\
Bathygobius fuscus & 2.9 & 0.9 & 24.8 & 1.2 \\
Others & 61.1 & & & \\
Total & 193.9 & & & \\
& & & & \\
\hline
\end{tabular}


Table 3. Mean percentage contribution and standard errors of 10 most abundant species within enclosed and open rotenone samples $(n=10)$

\begin{tabular}{|c|c|c|c|c|c|}
\hline \multicolumn{3}{|c|}{ Open } & \multicolumn{3}{|c|}{ Enclosed } \\
\hline Species & Mean \% & $\mathrm{SE}$ & Species & Mean \% & SE \\
\hline Neopomacentrus bankieri & 32.5 & 5.6 & Neopomacentrus bankieri & 31.0 & 6.3 \\
\hline Pomacentrus moluccensis & 12.7 & 3.1 & Pomacentrus moluccensis & 12.5 & 3.8 \\
\hline Chrysiptera rollandi & 5.4 & 2.1 & Eviota queenslandica & 10.6 & 2.4 \\
\hline Trimma striata & 4.5 & 2.7 & Pomacentrus adelus & 2.6 & 0.8 \\
\hline Amblygobius rainfordi & 3.5 & 2.4 & Gobiodon histrio & 2.2 & 0.9 \\
\hline Callogobius maculipinnis & 3.2 & 2.5 & Trimma striata & 2.1 & 1.0 \\
\hline Pomacentrus brachialis & 2.9 & 1.4 & Neopomacentrus azysron & 2.0 & 0.9 \\
\hline Ecsenius mandibularis & 2.8 & 2.5 & Eviota sp. F & 1.8 & 0.5 \\
\hline Eviota queenslandica & 2.6 & 1.0 & Eviota sp. C & 1.7 & 0.6 \\
\hline Pomacentrus adelus & 2.5 & 0.6 & Gobiodon brochus & 1.5 & 0.7 \\
\hline Others & 27.3 & & Others & 31.9 & \\
\hline
\end{tabular}

proportion of gobies, however, the species differed, with the large gobies Amblygobius rainfordi and Callogobius maculipinnis being major components. Despite the difference in species, there was little difference between open and enclosed samples in terms of the abundance of the dominant families (Fig. 2a), with slightly fewer pomacentrids but more gobies in enclosed samples.

In terms of familial species richness, there likewise appears to be little overall difference between the open and enclosed rotenone samples (Fig. 2b). Although more species were collected in the open stations, gobies showed the reverse pattern, with more species on average in the enclosed stations. This is noteworthy, given that the area outside was approximately 3 to 60 times larger than the area inside the net. This suggests that the smaller cryptic gobiid species are under-represented in large scale or open rotenone samples.

The relative abundance of the most prominent family, the Pomacentridae, was not reflected in its species richness (Fig. 3). Whilst they were consistently the numerically dominant family, the rotenone samples indicate that the Gobiidae were more diverse. The Pomacentridae were dominated by 2 species, with a relatively small contribution by less abundant species. In contrast, the Gobiidae contained numerous relatively rare species.

Comparisons between rotenone and visual techniques. Whilst rotenone and visual censuses appear broadly comparable in terms of abundant species, marked differences can be seen if the whole species list is examined. Of the 205 species censused, only $33.6 \%$ were common to both techniques. Of the 128 species censused using rotenone, $46.1 \%$ were detected using only that technique, whilst $52.7 \%$ of the 146 species censused visually were not recorded in the rotenone catches.
The most obvious difference between the 2 techniques is the greater abundance of gobies in rotenone samples compared to visual censuses (Fig. 1a,c). Another major difference is the low numbers of mobile
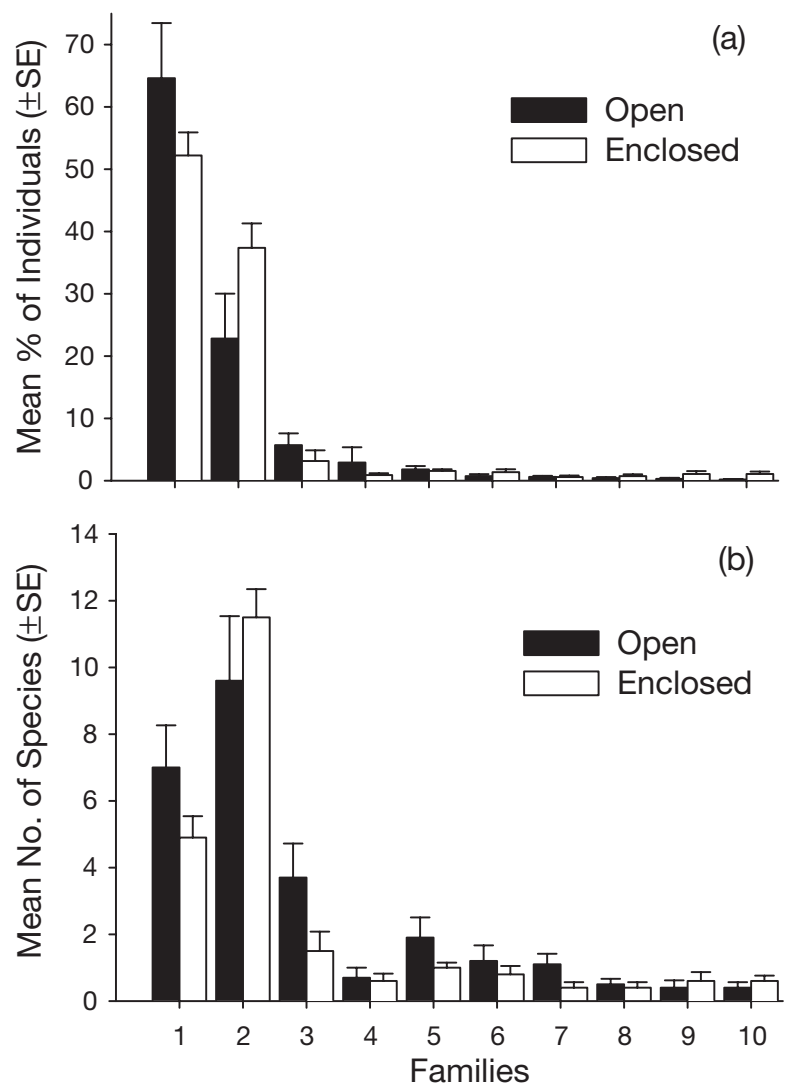

Fig. 2. Differences between top 10 families collected in open and enclosed rotenone stations. (a) Mean abundance $( \pm \mathrm{SE}$, $\mathrm{n}=10)$; (b) mean number of species $( \pm \mathrm{SE}, \mathrm{n}=10)$. 1: Pomacentridae; 2: Gobiidae; 3: Apogonidae; 4: Blenniidae; 5: Serranidae; 6: Labridae; 7: Pseudochromidae; 8: Chaetodontidae; 9: Tripterygiidae; 10: Bythitidae 


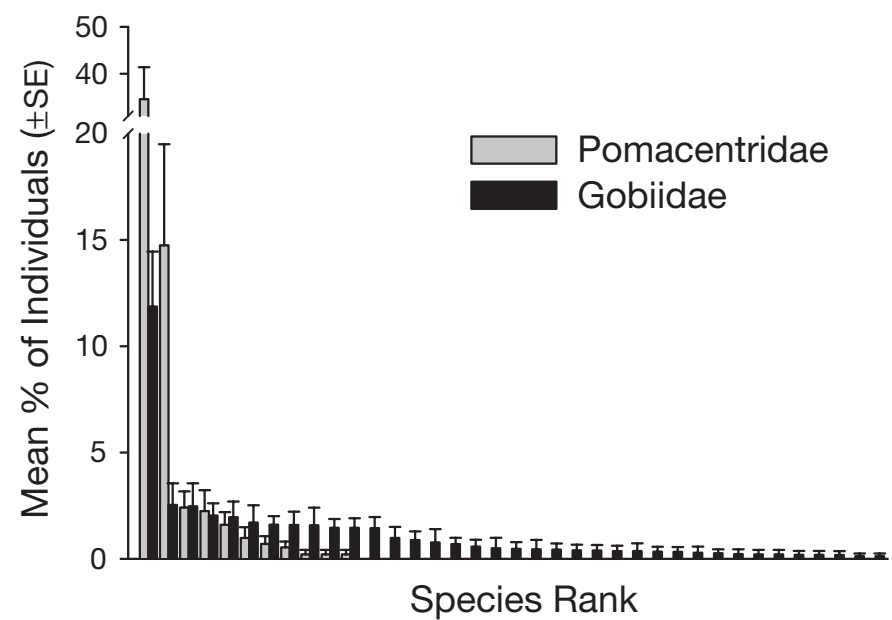

Fig. 3. Species rank within enclosed rotenone samples. Mean proportion $(\%)$ of species $( \pm \mathrm{SE})$ within Pomacentridae and Gobiidae $(\mathrm{n}=10)$

taxa in rotenone samples, e.g. Caesionidae, Scaridae, Nemipteridae, Siganidae, Haemulidae, Pomacanthidae, and Acanthuridae. Families in the rotenone samples that are rarely recorded in visual-reef fish censuses include the Pseudochromidae, Tripterygiidae, Bythitidae, Syngnathidae, Antennariidae and the Aploactinidae.

A comparable pattern was seen in visual-point censuses. Of the species present in the enclosed rotenone collections only $17.7 \%$ of them were seen in the visualpoint censuses prior to placing the net. This is emphasised in the principle-components analysis of the families censused between the enclosed rotenone samples and the preceding point censuses. Most of the variation is accounted for by PC $1(46.4 \%)$, which divides the 2 different censusing techniques (Fig. 4a). Negative scores on PC 1 correspond to visual-point censuses, driven by large numbers of pomacentrids, caesionids and labrids. Enclosed rotenone samples have positive scores on PC 1, and are characterised by large numbers of gobies. The Apogonidae, Blenniidae, Serranidae, Tripterygiidae, and Bythitidae, all cryptic by nature, also contribute to the division (Fig. 4b). The latter family was never seen in visual censuses; however, at least 1 individual was caught in every rotenone sample throughout the $5 \mathrm{yr}$ sampling regime.

To gain a more comprehensive picture of the portions of the reef fish assemblage revealed using each of the censusing techniques, a PCA was performed on all families censused. The first 2 components explain $60.4 \%$ of the variance, and reveal 2 distinct groups corresponding to rotenone and visual censuses. The visual category can be further divided into strip and point censuses (Fig. 5), the latter showing no distinction between the random-point censuses and the pre- (a)

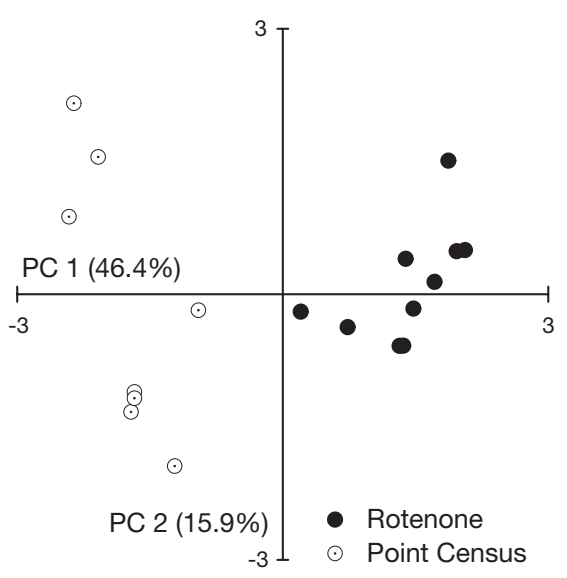

(b)

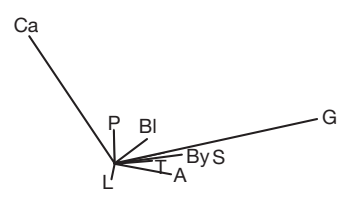

Fig. 4. Principal-components analysis (PCA) of all families censused in visual-point censuses (prior to rotenone, $\mathrm{n}=8$ ) and rotenone samples $(n=10)$. (a) Reduced space plot of scores for PC 1 and PC 2; (b) H-plot for family vectors (A: Apogonidae; Bl: Blenniidae; By: Bythitidae; Ca: Caesionidae; G: Gobiidae; L: Labridae; P: Pomacentridae; S: Serranidae; T: Tripterygiidae)

(a)

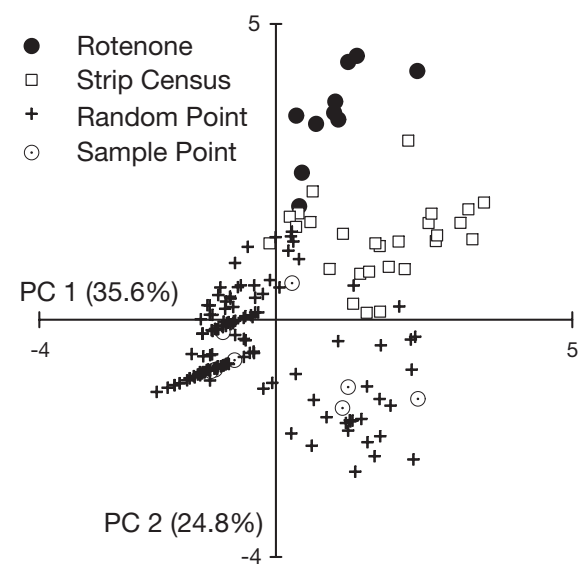

(b)

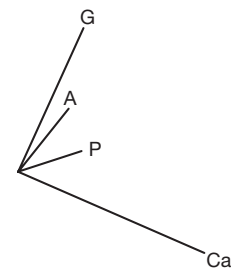

Fig. 5. PCA of all families censused over all techniques, strip transects $(n=27)$, visual-point censuses (prior to rotenone, $n=8)$, rotenone $(n=10)$, and random-point censuses $(n=135)$. (a) Reduced space plot of scores for PC 1 and PC 2; (b) H-plot for family vectors (abbreviations as in Fig. 4) 
rotenone censuses. This suggests that the rotenone sites were relatively representative samples with respect to the total fish assemblage. Most of the variation is accounted for by PC 1, which is driven largely by the abundance of the pomacentrids and caesionids. PC 2 appears to be driven by the small and/or cryptic taxa, i.e. gobies and apogonids.

The difference between the 2 methods becomes even more evident when comparing the estimated total lengths of fishes (Fig. 6). The modes of the 2 frequency distributions lie in different classes: 40 to $50 \mathrm{~mm}$ in visual censuses versus 30 to $40 \mathrm{~mm}$ in rotenone samples. Although rotenone is biased towards the smaller fishes, and a smaller mean is expected, it is striking that there is a change in the mode. It is noteworthy that this difference lies in size classes that are censused by visual surveys (i.e. 21 to 30 and 31 to $40 \mathrm{~mm}$ ). Visual censuses recorded only 44 fish per $10 \mathrm{~m}^{2}$ between 21 and $40 \mathrm{~mm}$ versus 102 per $10 \mathrm{~m}^{2}$ in rotenone samples, an underestimate of approximately $57 \%$. Moreover, fish in the smallest size class (11 to

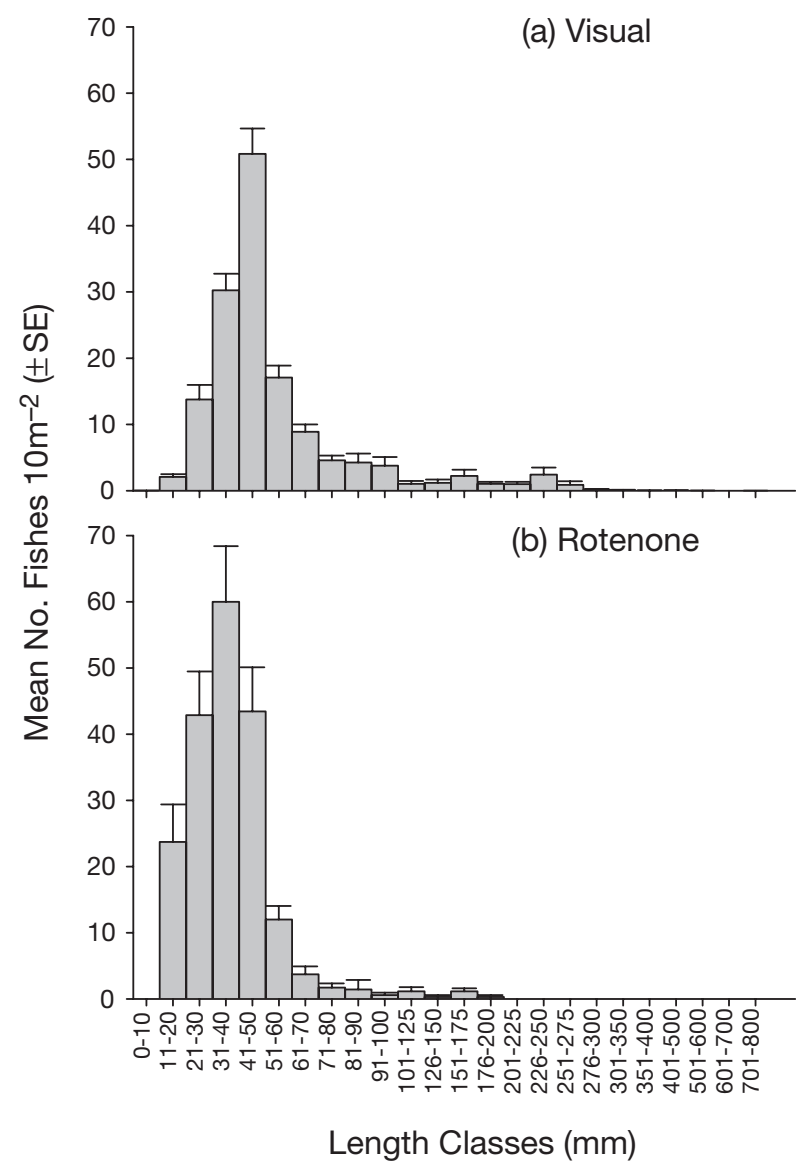

Fig. 6. Mean abundance of fish per $10 \mathrm{~m}^{2}$ grouped by length classes $( \pm \mathrm{SE})$. (a) Visual censuses by combined strip transects $(n=27)$. (b) Enclosed rotenone samples $(n=10)$
$20 \mathrm{~mm}$ ) appear to be grossly underestimated by visual techniques ( 2 versus 24 fish per $10 \mathrm{~m}^{2}$ for visual and rotenone collections, respectively). Overall, visual censuses provide an estimate of 146 ind. per $10 \mathrm{~m}^{2}$. Substituting rotenone counts for smaller size categories $(<50 \mathrm{~mm})$ increases this to 219 per $10 \mathrm{~m}^{2}$. An increase of $50.1 \%$ overall and $75.3 \%$ for individuals below $50 \mathrm{~mm}$.

Differences between underwater estimations of size in visual censuses and direct measurement of rotenone species do not account for the differences in the modes between visual and rotenone samples. The mean difference between the estimated length and the measured length was, on average, $18 \%( \pm 2 \mathrm{SE}$, $\mathrm{n}=11$ ) less than the actual length. In all cases, sizes were underestimated. The actual discrepancy between the 2 methods is therefore probably greater than indicated.

The estimated biomass of reef fishes based on visualswum transects was $2033 \mathrm{~kg} \mathrm{ha}^{-1}$. Approximately $50 \%$ of this biomass was fish between 226 and $275 \mathrm{~mm}$ in length, being predominantly schooling caesionids. Removing the Caesionidae enables the epi-benthic reef-fish biomass to be examined without the overriding influence of these reef-associated planktivores. The estimated epi-benthic reef-fish biomass is $1002 \mathrm{~kg}$ ha $^{-1}$ (Fig. 7), with the distribution amongst the size categories being relatively even, although the smallest size classes $(<50 \mathrm{~mm})$ account for $<10 \%$ of the total epi-benthic biomass (based on visual data only). Substitution of the rotenone biomass $(<50 \mathrm{~mm})$ has little effect on this value (from 9.7 to $10.7 \%$ ). Thus, while rotenone reveals numerous individuals not recorded in visual censuses (50.1\% more), its effect on estimates of biomass is limited (1.0\% more).

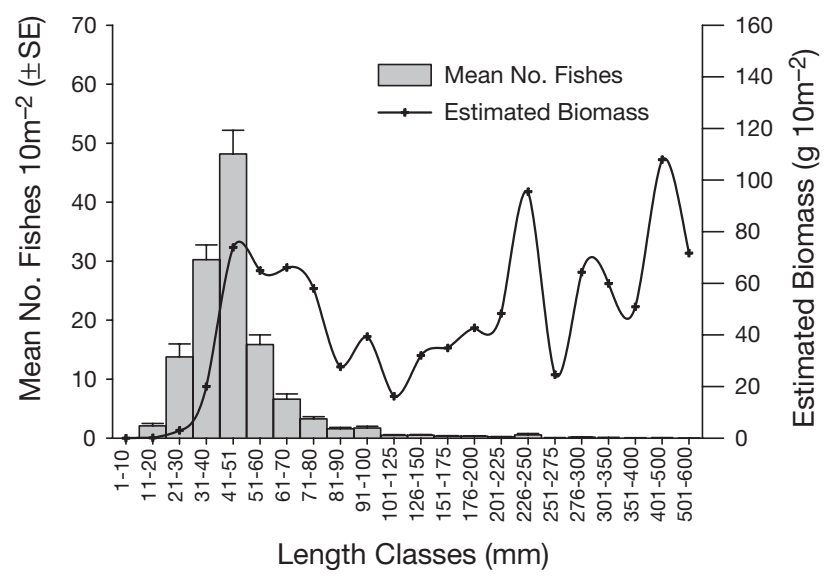

Fig. 7. Abundance and biomass of fishes in visual censuses: mean number of fish $( \pm \mathrm{SE})$ censused using combined visualstrip censuses and estimated biomass ( $\mathrm{g}$ ) for each length class $(\mathrm{n}=27)$, excluding reef-associated Caesionidae 


\section{DISCUSSION}

Since the early 1950s, our understanding of reef fish assemblages and the mechanisms responsible for their maintenance has relied heavily on data gathered by visual census techniques (overview in Sale 1991). Regardless of the patterns described and the processes inferred, these studies refer to only a subset of the assemblages. Small taxa are largely overlooked. The present study, through the use of small, intensively sampled, quantitative rotenone stations, directly examined the abundance and diversity of these small 'often ignored' taxa (sensu Munday \& Jones 1998).

The differences found between the open and enclosed rotenone samples demonstrate the value of examining a small enclosed area with intensive searching. The enclosed samples contained species that were neither seen prior to rotenone dispersal, nor collected in any abundance in the open samples. In the latter case there is a strong possibility of taxon-specific susceptibility, with mobile, cryptic and burrowing taxa avoiding the dispersing plume. Furthermore, the data obtained from enclosed stations are quantitative, i.e. from a definable area $\left(3.5 \mathrm{~m}^{2}\right)$. Open stations are of an indeterminate area (approximately 10 to $200 \mathrm{~m}^{2}$ ) and can only provide qualitative data on relative abundances. Previous studies in which rotenone has been used to gather quantitative estimates of fish density and biomass (Brock et al. 1979, Brock 1982) have used nets to enclose sites; however, the enclosed regions varied from 300 to $1500 \mathrm{~m}^{2}$. Intensive searching over such large areas would require a prohibitive length of time. To achieve the same intensity of collection as in the present study, at least 68000 diver-hours would be needed over the larger areas reported (at 45 diver $\min \mathrm{m}^{-2}$ ). As the enclosed rotenone samples differed markedly from the open samples with respect to the number of gobies collected, this intensity may be necessary to obtain an accurate representation of these small fishes. Small enclosed rotenone stations provide an invaluable tool for censusing small cryptic taxa. The small area, use of a fine net, quantity of rotenone dispersed, and the intensive examination of the substratum provide a detailed quantitative picture of the small taxa in the fish assemblage. Although larger more mobile species will be underestimated or excluded, rotenone appears to be an excellent method for censusing fishes that are overlooked by visual censuses.

Whilst the visual census data is broadly comparable with those of previous studies (e.g. Sale et al. 1994, Caley 1995, Bellwood 1996), the rotenone collections indicate that a significant proportion of the assemblage was not recorded. These taxa came in 2 forms: those that were censused, but underrepresented, such as the Gobiidae, and those that were missed altogether, such as the Bythitidae, Syngnathidae, Antennariidae, and Aploactinidae. Whether visually underrepresented or missed, the taxa revealed by rotenone collections were generally of a small body size.

This underrepresentation of small fishes in visual censuses has been reported for both diversity (Brock 1982, Kulbicki 1990) and abundance (Lincoln Smith 1988) of species and families. Brock's (1982) comparison of visual censuses versus rotenone, showed that 28 of the $81(34.6 \%)$ species collected by rotenone were not recorded in visual censuses. Likewise, Kulbicki (1990) found over $50 \%$ of species within rotenone collections were missed by visual censuses. The present study found similar results, with $46 \%$ of species present in the rotenone samples not detected in the visualstrip censuses.

The greatest underestimation by visual censuses appeared in the Gobiidae. This family, whilst rarely recorded in large numbers in visual censuses, were found to be extremely abundant in the rotenone samples, even compared to the Pomacentridae, which is often identified as one of the most abundant families on reefs (Williams \& Hatcher 1983, Sale et al. 1994). The Gobiidae are generally small fishes with strong substratum associations (Miller 1979). Their abundance therefore is difficult to record accurately, unless specifically searching for a particular species (Munday et al. 1997). The rotenone collections also revealed that the dominance of the Pomacentridae was based on the high abundance of only a few species, whilst the Gobiidae was comprised of many species of a moderate abundance, emphasising the diversity of small reef fishes (cf. Emery 1978).

The use of rotenone has revealed that smaller taxa are often overlooked in visual censuses. This is often acknowledged, with the reasons given ranging from the difficulty of estimating their abundance (Williams 1982, Bohnsack \& Bannerot 1986, Rooker et al. 1997), to the assumption that they were rarely present and could therefore be removed from the analysis (Caley \& St John 1996). It appears that this assumption may be invalid. Descriptions of reef-fish faunas based on visual censuses may be misleading and biasing our view of reef fish assemblages. The impression of abundance is driven largely by the visual appearance of the taxa. Pomacentrids, labrids, and chaetodontids are all visually striking and are frequently selected for detailed investigation (e.g. Doherty 1983, Roberts \& Ormond 1987, Meekan et al. 1995). However, the small taxa with close links to the substratum, such as the Gobiidae, may also be extremely abundant and worthy of further investigation. Abundance and diversity are often only judged relative to what is seen, and may not be indicative of what is actually present. The implications of this disparity may have far-reaching conse- 
quences when examining patterns in reef fish assemblages and the processes responsible for maintaining these patterns.

A number of ecological processes have been implicated in the maintenance of diversity and patterns in reef fish assemblages (reviewed by Jones 1991). Data presented when testing hypothesis regarding these processes are often collected using visual census methods. These methods only survey those reef fishes that are diurnally active and visually apparent. Missing species and misrepresenting the abundance of others (as in visual methods) may create difficulties in assessing competitive interactions, resource allocation, and most importantly the processes operating at a small scale, including the critical time at recruitment and in the early post-recruitment phase (Jones 1991, Hixon \& Beets 1993).

Small individuals have the potential to dominate resources and shape ecosystem function, simply by virtue of their large numbers; for example, with respect to bottom-up effects such as nutrient allocation or topdown effects such as predation. If either or both of these are the case, then these small taxa may be instrumental in determining assemblage structures. The present study emphasises the potential importance of small taxa in reef-fish processes. This is particularly clear in terms of biomass and its association with energetics.

The total estimated standing stock (2033 $\mathrm{kg} \mathrm{ha}^{-1}$ ) for Pioneer Bay is towards the high end of biomass estimates reported for coral reefs. Literature values range from $175 \mathrm{~kg} \mathrm{ha}^{-1}$ (Goldman \& Talbot 1976) to $2373 \mathrm{~kg}$ $\mathrm{ha}^{-1}$ (Williams \& Hatcher 1983). Although densities and species richness were underrepresented in visual censuses, total biomass estimates did not appear to change substantially with the additional data from the rotenone collections. This was expected, as the mean weight of fishes in the smaller size classes $(<50 \mathrm{~mm})$ range from approximately 0.05 to $1.2 \mathrm{~g}$. Therefore, a large increase in the number of small individuals will result in a relatively small increase in biomass. A similar study (using only the Scaridae) found that including fish in size classes $<100 \mathrm{~mm}$ increased the overall biomass estimate by approximately $10 \%$, even though the number of individuals increased by well over $100 \%$ (Bellwood \& Alcala 1988).

The present study found fish $<100$ and $<50 \mathrm{~mm}$ to represent only 35.2 and $9.7 \%$ of the biomass, respectively. This may appear irrelevant to studies related to fisheries yields (cf. Bellwood 1988); however, with respect to the ecosystem the biomass of these small fishes may be disproportionately important in terms of the total resources used, due to their specific metabolic rates. Estimates using Mann's (1965) formula for fish metabolic rates, $Q=0.336 w^{0.8}$ (where $Q=$ metabolic rate and $w=$ individual fish weight, based on the mean weight of individuals in each size class) indicate that fishes up to $50 \mathrm{~mm}$ may be using over $25 \%$ of the total energy required by epi-benthic reef fish, whilst fishes up to $100 \mathrm{~mm}$ may use over $57 \%$ (Fig. 8). Although these are only provisional estimates, they nevertheless emphasis the potential importance of small fishes in reef processes.

In addition to high specific metabolic rates, small fishes may have a shorter life cycle (Miller 1979). This has further implications for the role that they play within the reef system. The standing stock does not necessarily reflect the productivity of these fishes. If their maximum expected age is less than a year, as in the small goby Aphia minuta (Iglesias et al. 1997), then their productivity will be greatly underestimated by instantaneous biomass estimates. If this is the case, their total impact upon the reef community may be much greater than anticipated. The 3 most abundant families within the rotenone collections, the Pomacentridae, Gobiidae and Apogonidae, are all common prey items for piscivorous fishes (Parrish et al. 1986). Moreover, piscivorous fishes may have greater success capturing smaller fishes (Juanes 1994). Through greater energetic demands, high turnover rates and their role as potential prey, small reef fish taxa may play a disproportionately large role in reef processes. Further emphasis needs to be placed on gathering metabolic,

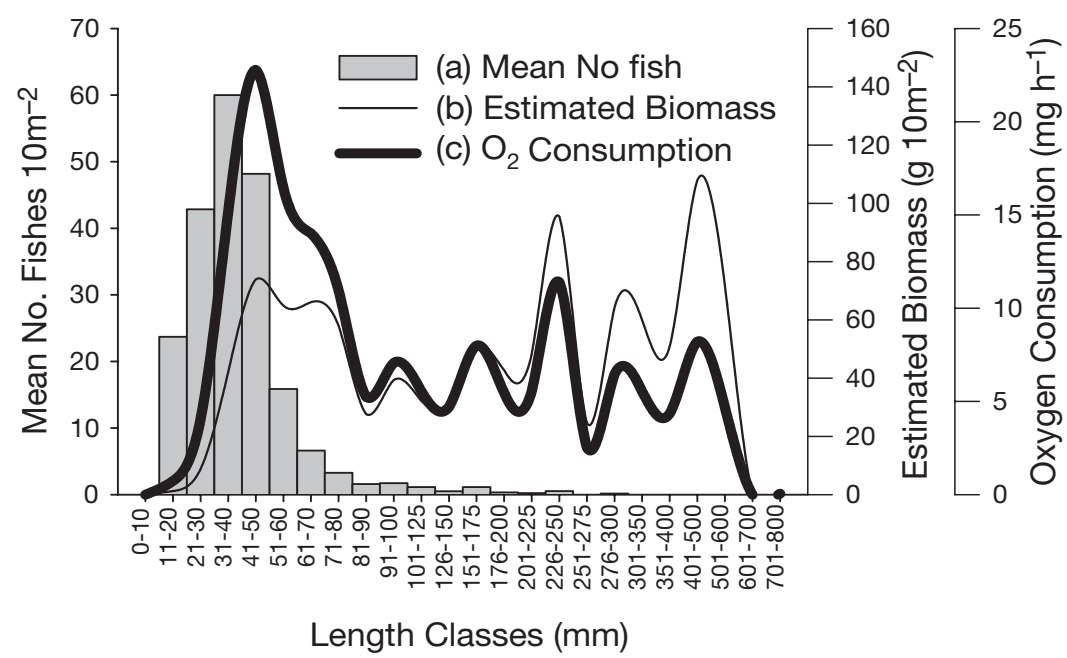

Fig. 8. Relationship between fish length-classes and numbers of fishes, estimated biomass, and estimated metabolic rate. a \& b modified from combinations of Figs. 6b \& 7, and c based on Mann's (1965) formula $Q=0.336 w^{0.8}$ (where $Q=$ metabolic rate measured as oxygen consumption and $w=$ weight 
trophic, life history, and accurate abundance data on these small fishes if we are to appreciate their contribution to reef systems.

In a review of small reptiles, Avery (1996) summarised his findings as 'essentially a catalogue of ignorance', as the smaller species were rarely studied and their systematics rarely known. The same holds true for coral reef fishes. Visual censuses have become the reef-fish ecologists primary tool because of their repeatability and ease of use. The inherent biases against the smaller individuals and species are well known, and are generally accepted without question. Rotenone has revealed that the missing component includes the most abundant and species-rich size classes as well as a significant proportion of the total numbers and biomass of fishes on the reef. Overall, we may be missing a critical component in reef processes.

Acknowledgements. We wish to thank the James Cook University Reef Fish Biology students, the goby-pickers, for help in fish collection; Jake Kritzer for field assistance; Philip Munday for help with fish identifications; Natalie Moltschaniwskyj for statistical advice and the staff of Orpheus Island Research Station for field support. This study was supported by the Australian Research Council (D.R.B.). We appreciate the vision of the Great Barrier Reef Marine Park Authority, the Department of Environment, and the Queensland Fisheries Management Authority for permission to undertake this work. JCU Experimentation Ethics Review Committee Approval \#A428.

\section{LITERATURE CITED}

Avery RA (1996) Ecology of small reptile-grade sauropsids. Symp Zool Soc Lond 69:225-237

Bell JD, Galzin R (1984) Influence of live coral cover on coralreef fish communities. Mar Ecol Prog Ser 15:265-274

Bellwood DR (1988) Seasonal changes in the size and composition of the fish yield from reefs around Apo Island, Central Philippines, with notes on methods of yield estimation. J Fish Biol 32:881-893

Bellwood DR (1996) The Eocene fishes of Monte Bolca: the earliest coral reef fish assemblage. Coral Reefs 15:11-19

Bellwood DR, Alcala AC (1988) The effect of a minimum length specification on visual estimates of density and biomass of coral reef fishes. Coral Reefs 7:23-27

Blackburn TM, Gaston KJ (1996) Abundance-body size relationships: the area you census tells you more. Oikos 75 : 303-309

Bohnsack JA, Bannerot SP (1986) A stationary visual census technique for quantitatively assessing community structure of coral reef fishes. NOAA Natn Mar Fish Serv Tech Rep 41:1-15

Brock RE (1982) A critique of the visual census method for assessing coral reef fish populations. Bull Mar Sci 32: 269-276

Brock RE, Lewis C, Wass RC (1979) Stability and structure of a fish community on a coral patch reef in Hawaii. Mar Biol 54:281-292

Brock VE (1954) A preliminary report on a method of estimating reef fish populations. J Wildl Mgmt 18:297-308

Caley MJ (1995) Community dynamics of tropical reef fishes: local patterns between latitudes. Mar Ecol Prog Ser 129: $7-18$

Caley MJ, St John J (1996) Refuge availability structures assemblages of tropical reef fishes. J Anim Ecol 65:414-428

Choat JH, Bellwood DR (1985) Interactions amongst herbivorous fishes on a coral reef: influence of spatial variation. Mar Biol 89:221-234

Choat JH, Bellwood DR (1991) Reef fishes: their history and evolution. In: Sale PF (ed) The ecology of fishes on coral reefs. Academic Press, San Diego, p 46-53

Davis GE, Anderson TW (1989) Population estimates of four kelp forest fishes and an evaluation of three in situ assessment techniques. Bull Mar Sci 44:1138-1151

Doherty PJ (1983) Tropical territorial damselfishes: is density limited by aggression or recruitment? Ecology 64:176-190

Emery AR (1978) The basis of fish community structure: marine and freshwater comparisons. Environ Biol Fish 3:33-47

Fowler AJ (1987) The development of sampling strategies for population studies of coral reef fishes. A case study. Coral Reefs 6:49-58

Goldman B, Talbot FH (1976) Aspects of the ecology of coral reef fishes. In: Jones OA, Endean R (eds) Biology and geology of coral reefs. Academic Press, New York, p 125-154

Hixon MA, Beets JP (1993) Predation, prey refuges, and the structure of coral-reef fish assemblages. Ecol Monogr 63:77-101

Iglesias M, Brothers EB, Morales-Nin B (1997) Validation of daily increment deposition in otoliths. Age and growth determination of Aphia minuta (Pisces: Gobiidae) from the Northwest Mediterranean. Mar Biol 129:279-287

Jones GP (1991) Postrecruitment processes in the ecology of coral reef fish populations: a multifactorial perspective. In: Sale PF (ed) The ecology of fishes on coral reefs. Academic Press, San Diego, p 294-330

Jones RS, Chase JA (1975) Community structure and distribution of fishes in an enclosed high island lagoon in Guam. Micronesia 11:127-148

Juanes F (1994) What determines prey size selectivity in piscivorous fishes? In: Stouder DJ, Fresh KL, Feller RJ (eds) Theory and application in fish feeding ecology. University of South Carolina Press, Colombia, p 79-100

Kulbicki M (1990) Comparisons between rotenone poisonings and visual counts for density and biomass estimates of coral reef fish populations. In: Ricard M (ed) Proceedings International Society for Reef Studies (ISRS) Congress, Noumea. Université française du Pacifique, Papeete, Tahiti, p 105-112

Kulbicki M, Moutham G, Thollot P, Wantiez L (1993) Lengthweight relationships of fish from the lagoon of New Caledonia. Naga (ICLARM Q) April-July:26-30

Lincoln Smith MP (1988) Effects of observer swimming speed on sample counts of temperate rocky reef fish assemblages. Mar Ecol Prog Ser 43:223-231

Luckhurst BE, Luckhurst K (1978) Analysis of the influence of substrate variables on coral reef fish communities. Mar Biol 49:317-323

Mann KH (1965) Energy transformations by a population of fish in the river Thames. J Anim Ecol 34:253-275

Masuda H, Amaoka K, Araga C, Uyeno T, Yoshino T (1984) The fishes of the Japanese Archipelago. Tokai University Press, Tokyo

Meekan MG, Choat JH (1997) Latitudinal variation in abundance of herbivorous fishes: a comparison of temperate and tropical reefs. Mar Biol 128:373-383

Meekan MG, Steven ADL, Fortin MJ (1995) Spatial patterns in the distribution of damselfishes on a fringing coral reef. Coral Reefs 14:151-161 
Miller PJ (1979) Adaptiveness and implications of small size in teleosts. Symp Zool Soc Lond 44:263-306

Munday PL, Jones GP (1998) The ecological implications of small body size among coral-reef fishes. Oceanogr Mar Biol Annu Rev 36:373-411

Munday PL, Wilson SK (1997) Comparative efficacy of clove oil and other chemicals in anaesthetization of Pomacentrus amboinensis, a coral reef fish. J Fish Biol 51:931-938

Munday PL, Jones GP, Caley MJ (1997) Habitat specialisation and the distribution and abundance of coral-dwelling gobies. Mar Ecol Prog Ser 152:227-239

Murdy EO, Hoese DF (1985) Revision of the gobiid fish genus Istigobius. Indo-Pac Fish 4:1-41

Myers RF (1989) Micronesian reef fish. Coral Graphics, Barrigada

Parrish JD, Norris JE, Callahan MW, Callahan JK, Magarifuji EJ, Schroeder RE (1986) Piscivory in a coral reef fish community. In: Simenstad CA, Cailliet GM (eds) Contemporary studies on fish feeding: the proceedings of gutshop '84. Environ Biol Fish 7:285-298

Randall JE (1963) An analysis of the fish populations of artificial and natural reefs in the Virgin Islands. Caribb J Sci 3:31-47

Randall JE, Allen GR, Steene RC (1990) Fishes of the Great Barrier Reef and Coral Sea. Crawford House, Bathurst

Roberts CM, Ormond RFG (1987) Habitat complexity and coral reef fish diversity and abundance in Red Sea fringing reefs. Mar Ecol Prog Ser 41:1-8

Rooker JR, Dokken QR, Pattengill CV, Holt GJ (1997) Fish assemblages on artificial and natural reefs in the Flower Garden Banks National Marine Sanctuary, USA. Coral Reefs 16:83-92

Russ GR (1989) Distribution and abundance of coral reef fishes in the Sumilon Island Reserve, Central Philippines, after nine years of protection from fishing. Asian Mar Biol 6:59-71

Sale PF (1991) The ecology of fishes on coral reefs. Academic Press, New York

Editorial responsibility: Charles Birkeland (Contributing Editor), Mangilao, Guam
Sale PF, Douglas WA (1981) Precision and accuracy of visual census technique for fish assemblages on coral patch reefs. Environ Biol Fish 6:333-339

Sale PF, Guy JA, Steel WJ (1994) Ecological structure of assemblages of coral reef fishes on isolated patch reefs. Oecologia 98:83-99

Shepherd ARD, Warwick RM, Clarke KR, Brown BE (1992) An analysis of fish community responses to coral mining in the Maldives. Environ Biol Fish 33:367-380

Smith CL (1973) Small rotenone stations: a tool for studying coral reef fish communities. Am Mus Novit 2512:1-21

St John J, Russ GR, Gladstone W (1990) Accuracy and bias of visual estimates of numbers, size structure and biomass of a coral reef fish. Mar Ecol Prog Ser 64:253-262

Thompson AA, Mapstone BD (1997) Observer effects and training in underwater visual surveys of reef fishes. Mar Ecol Prog Ser 154:53-63

Watson RA, Carlos GM, Samoilys MA (1995) Bias introduced by the non-random movement of fish in visual transect surveys. Ecol Model 77:205-214

Williams DMcB (1982) Patterns in the distribution of fish communities across the Central Great Barrier Reef. Coral Reefs 1:35-43

Williams DMcB, Hatcher AI (1983) Structure of fish communities on outer slopes of inshore, mid-shelf and outer shelf reefs of the Great Barrier Reef. Mar Ecol Prog Ser 10: $239-250$

Winterbottom R (1984) A review of the gobiid fish genus Trimma from the Chagos Archipelago, Central Indian Ocean, with the description of seven new species. Can J Zool 62:695-715

Winterbottom R (1985) Two new gobiid fish species (in Priolepsis and Trimma) from the Chagos Archipelago, Central Indian Ocean. Can J Zool 63:748-754

Winterbottom R, Emery AR (1986) Review of the Gobioid fishes of the Chagos Archipelago, Central Indian Ocean. R Ont Mus Life Sci Contrib 142:1-82

Submitted: November 3, 1999; Accepted: March 27, 2000

Proofs received from author(s): October 4, 2000 